\title{
PENGEMBANGAN MEDIA GAMBAR TIGA DIMENSI POP UP DALAM PEMBELAJARAN MENULIS PUISI DI KELAS VIII SMPN 1 UJAN MAS KEPAHIANG TAHUN AJARAN 2016/2017
}

\author{
Mully Cahyani Byari, Arono, dan Gumono \\ Program Studi Pendidikan Bahasa dan Sastra Indonesia \\ Jurusan Pendidikan Bahasa dan Seni \\ FKIP Universitas Bengkulu \\ mullycahyanibyari@gmail.com
}

\begin{abstract}
Abstrak
Penelitian ini bertujuan untuk mengembangkan media gambar tiga dimensi pop up dalam pembelajaran menulis puisi di kelas VIII SMP Negeri 1 Ujan Mas Kabupaten Kepahiang Tahun Ajaran 2016/2017. Metode yang digunakan dalam penelitian ini adalah penelitian dan pengembangan. Subjek penelitian ini adalah kelas VIII A yang berjumlah 29 siswa. Teknik pengumpulan data dilakukan dengan teknik observasi, wawancara, dan angket. Teknik analisis data dilakukan dengan cara menghitung jumlah persentase dari hasil menulis puisi. Hasil penelitian menunjukkan bahwa SMPN 1 Ujan Mas membutuhkan media pada saat proses pembelajaran, dengan adanya media dapat membantu meningkatkan motivasi siswa, dalam pembelajaran. Dalam penelitian pengembangan ini, peneliti mengacu pada model penelitian dan pengembangan (R\&D) yang terdiri atas beberapa langkah sebagai berikut: (1) analisis kebutuhan, (2) pengembangan media gambar tiga dimensi pop up, (3) implementasi media gambar tiga dimensi pop up. Persentase yang dihasilkan siswa dalam menulis puisi menggunakan media gambar tiga dimensi pop up adalah sebesar $76,96 \%$. Berdasarkan analisis data dapat disimpulkan bahwa penggunaan media gambar tiga dimensi pop up dapat membantu siswa dalam menulis puisi. Proses pembelajaran berlangsung lebih menarik menggunakan media gambar tiga dimensi pop up.
\end{abstract}

Kata Kunci: media pembelajaran, pop up, puisi

\begin{abstract}
This research aimed to examine and develop three-dimensional drawing media pop up in learning to writing poetry in class VIII SMP Negeri 1 Ujan Mas Kepahiang Regency Year 2016/2017. The method used in this research is research and development. The subject of this research is the class VIII A which amounts to 29 students. Technique of collecting data by observation, interview, and questionnaire. Data analysis technique is done by counting the number of percentage of the result of writing poetry. The results showed that SMPN 1 Ujan Mas needed media during the learning process, with the media can help improve students' motivation, in learning. In this research development, the researcher refers to research and development model ( $R \& D$ ) consisting of several steps as follows: (1) needs analysis, (2) development of three dimensional pop-up image media, (3). The percentage of students generated in writing poetry using three dimensional pop-up images is $76.96 \%$. Based on the data analysis can be concluded the use of three-dimensional drawing media pop ups can help students in writing poetry. The learning process takes place more interesting using the three dimensional pop-up images.
\end{abstract}

Keywords: learning media, pop ups, poetry 


\section{PENDAHULUAN}

Pemilihan bahan pengajaran puisi hendaknya dilakukan dengan mempertimbangkan aspek bahasa, kematangan atau perkembangan jiwa siswa, dan latar belakang budaya. Salah satu tujuan pengajaran puisi kepada siswa adalah agar siswa memperoleh kesenangan dari pembaca dan mempelajari puisi sehingga tumbuh keinginan membaca dan mempelajari puisi pada waktu senangnya.

Berdasarkan pengamatan peneliti di sekolah pada materi pembelajaran bahasa yang membahas tentang menulis puisi, masih ada guru yang mengajar dengan cara konvensional, yaitu dengan cara menerangkan materi tentang cara menulis puisi lalu menyuruh siswa untuk membuat puisi terhadap materi yang disampaikan oleh guru mengenai menulis puisi.

Penggunaan media untuk mata pelajaran Bahasa Indonesia ini masih minim. Kenyataan tersebut mendorong peneliti untuk memberikan inovasi dalam pembelajaran yaitu pengembangan bahan ajar berupa media gambar tiga dimensi pop up. Media gambar tiga dimensi pop up merupakan media yang menampilkan halaman-halaman yang berisi gambar dalam bentuk tiga dimensi yang dapat pula digerakkan sehingga tidak membosankan pembacanya.

Media gambar tiga dimensi pop up juga bersifat konkret, yang berarti lebih realistis daripada media verbal. Gambar tiga dimensi yang dirancang dilengkapi dengan ilustrasi yang jelas dan menarik dalam penyampaian materi, informasi terbaru, sehingga bersifat interaktif terhadap siswa. Elemen kejutan yang didapat dari setiap halaman buku gambar tiga dimensi saat dibuka berperan penting dalam perkembangannya. Peneliti mengharapkan media gambar tiga dimensi pop up ini dapat memberikan hasil yang maksimal dalam mempelajari Bahasa Indonesia khususnya pada pembelajaran materi menulis puisi siswa kelas VIII SMPN 1 Ujan Mas Kabupaten Kepahiang.

Berdasarkan persoalan inilah, penulis tertarik untuk melakukan penelitian tentang pengembangan media gambar tiga dimensi pop up dan implementasi media gambar tiga dimensi pop up yang digunakan dalam pembelajaran menulis puisi pada siswa kelas VIII SMPN 1 Ujan Mas Kabupaten Kepahiang Tahun Ajaran 2016/2017.

Media pembelajaran adalah sebuah alat yang berfungsi dan digunakan untuk menyampaikan pesan pembelajaran. Pembelajaran adalah proses komunikasi antara pembelajar, pengajar, dan bahan ajar. Dapat dikatakan bahwa, bentuk komunikasi tidak akan berjalan tanpa bantuan sarana untuk menyampaikan pesan. Bentuk-bentuk stimulus dapat dipergunakan sebagai media,di antaranya adakah hubungan atau interaksi manusia, realitas, gambar bergerak atau tidak,tulisan dan suara yang direkam. Maka dengan kelima bentuk stimulus ini, akan membantu pembelajar mempelajari bahan pelajaran. Atau, dapat disimpulkan bahwa bentuk-bentuk stimulus yang dapat digunakan sebagai media pembelajaran adalah suara, lihat, dan gerakan (Sanaky, 2009:3).

Schramm mengatakan media adalah teknologi pembawa informasi atau pesan instruksional. Miarso, mengatakan bahwa media adalah segala sesuatu yang dapat digunakan untuk merangsang pikiran, perasaan, perhatian dan kemajuan pembelajar sehingga dapat mendorong terjadinya proses belajar pada diri pembelajarnya. Maka secara umum media adalah "alat bantu" yang dapat digunakan dalam proses pembelajaran (Sanaky, 2009:3)

Dapat disimpulkan bahwa media pembelajaran adalah sarana pendidikan 
yang dapat digunakan sebagai perantara dalam proses pembelajaran untuk mempertinggi efektifitas dan efisiensi dalam mencapai tujuan pengajaran. Dalam pengertian yang lebih luas media pembelajaran adalah alat, metode, dan teknik yang digunakan dalam rangka lebih mengefektifkan komunikasi dan interaksi antara pengajar dan pembelajar dalam proses pembelajaran di kelas.

Dalam buku Media Pembelajaran (Sanaky, 2009:3) menjelaskan bahwa tujuan media pembelajaran sebagai alat bantu mempermudah proses pembelajaran di kelas, meningkatkan efisiensi proses pembelajaran, menjaga relevansi antara materi pelajaran dengan tujuan belajar, dan membantu konsentrasi pembelajar dalam proses pembelajaran.

Manfaat media pembelajaran sebagai alat bantu dalam proses pembelajaran adalah untuk membuat pembelajaran lebih menarik. Metode pembelajaran bervariasi, tidak sematamata hanya komunikasi verbal melalui penuturan kata-kata lisan pengajar, pembelajar tidak bosan, dan pengajar tidak kehabisan tenaga,

Setelah mengetahui tujuan dan manfaat media pembelajaran, langkah selanjutnya adalah menentukan pilihan media yang akan digunakan dalam pembelajaran menjadi perhitungan utama, karena media yang dipilih harus sesuai dengan: tujuan pengajaran, bahan pelajaran, metode mengajar, tersedia alat yang dibutuhkan, pribadi pengajar, minat dan kemampuan pembelajar, dan situasi pengajaran yang sedang berlangsung (Sanaky, 2009:5).

Keterkaitan antara media pembelajaran dengan tujuan, materi, metode, dan kondisi pembelajar, harus menjadi perhatian dan pertimbangan pengajar untuk memilih dan menggunakan media dalam proses pembelajaran di kelas, sehingga media yang digunakan lebih efektif dan efisien untuk mencapai tujuan pembelajaran.

Gambar tiga dimensi pop up merupakan sebuah buku yang memiliki bagian yang dapat bergerak ketika halaman buku dibuka sehingga konstruksi kertas pada halaman berubah. Sekilas gambar tiga dimensi pop up hampir sama dengan origami dimana kedua seni ini mempergunakan teknik melipat kertas. Walau demikian, origami lebih memfokuskan diri pada menciptakan objek atau benda sedangkan gambar tiga dimensi pop up lebih cenderung pada pembuatan mekanis kertas yang dapat membuat gambar tampak secara lebih berbeda baik dari sisi perspektif/dimensi, perubahan bentuk hingga dapat bergerak yang disusun sealami mungkin (Dzuanda, 2009:7).

Buku gambar tiga dimensi pop up dapat memberikan visualisasi cerita yang lebih menarik. Mulai dari tampilan gambar yang terlihat lebih memiliki dimensi, gambar yang dapat bergerak ketika halamannya dibuka atau bagiannya digeser, bagian yang dapat berubah bentuk, memiliki tekstur seperti benda aslinya bahkan beberapa ada yang dapat mengeluarkan bunyi. Hal-hal seperti ini membuat ceritanya lebih menyenangkan dan menarik untuk dinikmati.

Hal lain yang membuat buku gambar tiga dimensi pop up menarik dan berbeda dari buku biasa adalah ia memberikan kejutan-kejutan dalam setiap halamannya yang dapat mengundang ketakjuban ketika halamannya dibuka. Hal ini membuat pembaca memancing antusias pembaca dalam mengikuti alur cerita buku karena mereka menanti kejutan apa lagi yang akan diberikan di halaman selanjutnya.

Buku gambar tiga dimensi pop up mempunyai kemampuan untuk memperkuat kesan yang ingin disampaikan dalam sebuah ilustrasi. Tampilan visual 
yang lebih berdimensi membuatnya semakin terasa nyata ditambah lagi dengan kejutan yang diberikan dalam setiap halamannya. Gambar dapat secara tiba-tiba muncul dari balik halaman atau sebuah bangunan dapat berdiri megah ditengah-tengah halaman dengan cara visualisasi ini, kesan yang ingin ditampilkan dapat lebih tersampaikan (Dzuanda, 2009:13).

Pada penelitian yang saya lakukan ini gambar tiga dimensi pop up yang akan saya kembangkan adalah jenis transformasi jenis gambar tiga dimensi pop up menunjukkan perubahan bentuk serta gerakan objek secara vertikal. Perubahan bentuk ditunjukkan dengan menarik atau membuka halaman kertas ke samping sehingga slide bagian bawah dan bagian atas bergerak dan konstruksi objek berubah.

Puisi adalah bentuk karya sastra yang tersaji secara monolog, menggunakan kata-kata yang indah dan kaya akan makna (Kosasih, 2008:32). Keindahan puisi ditentukan oleh diksi, majas, rima dan iramanya. Adapun kekayaan makna yang terkandung dalam puisi disebabkan oleh pemadatan segala unsur bahasa. Bahasa yang digunakan dalam puisi berbeda dengan yang digunakan sehari-hari. Puisi menggunakan bahasa yang ringkas, tetapi maknanya sangat kaya. Kata yang digunakannya adalah kata konotatif yang mengandung banyak penafsiran dan pengertian.

Puisi, Prosa dan Pantun Lama, Puisi merupakan salah satu bentuk karya sastra yang diwujudkan dengan kata-kata indah dan bermakna dalam. Dibanding karyakarya sastra yang lain, puisi termasuk dalam kategori karya sastra paling tua. Sebab, kemunculnya sudah lebih dahulu daripada karya-karya sastra yang lain, seperti cerpen, dongeng, novel, hikayat, dan sebagainya (Wahyuni, 2014:12).
Sedangkan menurut Sanusi Pane dalam Atmazaki (1933:5) puisi adalah katakata yang keluar dari sukma, karena kepuitisannya, mampu menerangi hati manusia yang menikmatinya (Ganie, 2015:59).

Secara garis besar, unsur-unsur puisi terbagi menjadi dua macam, yakni struktur fisik dan struktur batin (Kosasih, 2008:38). Berikut ini adalah unsur-unsur puisi:

Unsur fisik meliputi hal-hal berikut ini:

\section{a. Diksi (Pemilihan Kata) \\ Kata-kata yang digunakan dalam} puisi merupakan hasil pemilihan yang sangat cermat. Kata-katanya merupakan hasil pertimbangan, baik makna, susunan bunyinya, maupun hubungan kata dengan kata-kata lain dalam baris dan batinya.

\section{b. Pengimajian}

Pengimajian dapat didefinisikan sebagai kata atau susunan kata yang dapat menimbulkan khayalan atau imajinasi. Dengan daya imajinasi tersebut, pembaca seolah-olah merasa, mendengar atau melihat sesuatu yang diungkapkan penyair.

\section{c. Kata Konkret}

Untuk membangkitkan imajinasi pembaca, kata-kata harus diperkonkret atau diperjelas. Jika penyair mahir memperkonkret kata, pembaca seolaholah melihat, mendengar, atau merasakan apa yang dilukiskan oleh penyair. Pembaca dapat membayangkan secara jelas peristiwa atau keadaan yang dilukiskan oleh penyair.

\section{d. Bahasa Figuratif (Majas) \\ Majas (figurative language) adalah bahasa yang digunakan oleh penyair untuk mengatakan sesuatu dengan cara membandingkannya dengan benda atau kata lain. Majas mengiaskan atau menyamkan sesuatu dengan hal lain.}


Maksudnya, agar benda yang dibandingan itu lebih jelas, misalnya untuk menggambarkan keadaan ombak penyair menggunakan majas personifikasi atau majas yang lainnya.

\section{e. Rima/Ritma}

Rima adalah pengulangan bunyi dalam puisi. Dengan adanya rima, suatu puisi menjadi indah. Makna yang ditimbulkannya pun lebih kuat, seperti petikan sajak berikut ini: "Dan angin mendesah/mengeluh mendesah". Di samping rima, dikenal pula istilah ritma yang diartikan sebagai pengulangan kata, frase atau kalimat dalam bait-bait puisi.

\section{METODE}

Metode penelitian yang digunakan dalam penelitian ini adalah penelitian dan pengembangan (R\&D). Menurut Sugiyono (2015:30) metode penelitian dan pengembangan merupakan metode penelitian yang digunakan untuk menghasilkan suatu produk tertentu dan menguji keefektifan produk tersebut. Metode penelitian dan pengembangan dapat diartikan sebagai cara ilmiah untuk meneliti, merancang, memproduksi dan menguji validitas produk yang telah dihasilkan.

Penelitian ini dilaksanakan pada siswa kelas VIII SMPN 1 Ujan Mas Kabupaten Kepahiang Tahun Ajaran 2016/2017. Waktu penelitian ini akan dilaksanakan pada bulan Januari sampai dengan bulan Februari. Subjek penelitian ini ialah siswa kelas VIIIA SMPN 1 Ujan Mas Kabupaten Kepahiang Tahun Ajaran 2016/2017 yang berjumlah 29 orang.

Dalam penelitian pengembangan ini, peneliti mengacu pada model penelitian dan pengembangan (R\&D) menurut Borg dan Gall dalam Nana Syaodih (2010:169) yang terdiri atas beberapa langkah sebagai berikut: (1) Melakukan studi pendahuluan (2) Analisis
Kebutuhan (3) Perencanaan, Pengembangan draf produk, (5) Uji coba produk.

\section{HASIL DAN PEMBHASAN}

Produk yang dikembangkan dalam penelitian dan pengembangan ini adalah media pembelajaran untuk menulis puisi. Media pembelajaran tersebut berupa media gambar tiga dimensi pop up untuk pembelajaran menulis puisi siswa kelas VIII SMP. Media pembelajaran yang dikembangkan tersebut bersifat interaktif, yaitu dapat digunakan secara klasikal. Siswa dapat menggunakan dimanapun dan kapanpun asalkan ada media gambar tiga dimensi pop up.

Penelitian dan pengembangan yang dilakukan ini mengadaptasi dari sepuluh langkah pengembangan yang disampaikan oleh Borg dan Gall yang kemudian disederhanakan menjadi lima langkah. Lima langkah tersebut adalah melakukan studi pendahuluan, analisis kebutuhan, desain produk, pengembangan draf produk, dan uji coba produk.

Tahap pertama yang dilakukan peneliti dalam penelitian dan pengembangan ini yaitu studi pendahuluan. Studi pendahuluan yang dilakukan peneliti yaitu mencari informasi yang dibutuhkan oleh peneliti dalam penelitian ini meliputi tentang guru, materi pembelajaran dan media yang digunakan di SMPN 1 Ujan Mas. Studi pendahuluan ini dilakukan untuk mengetahui gambaran awal yang ada di SMPN 1 Ujan Mas.

Peneliti bertanya kepada guru Bahasa Indonesia SMPN 1 Ujan Mas. Ternyata pembelajaran Bahasa Indonesia yang berlangsung di SMPN 1 Ujan Mas belum menggunakan media. Peneliti juga bertanya kepada guru SMPN 1 Ujan Mas metode yang digunakan dalam pembelajaran Bahasa Indonesia yang digunakan oleh guru selama proses pembelajaran. Siswa juga banyak yang 
tertarik ketika peneliti bertanya tentang media pembelajaran.

Berdasarkan studi pendahuluan yang telah dilakukan oleh peneliti bahwa faktanya di SMPN 1 Ujan Mas membutuhkan media untuk meningktakan motivasi dalam menulis puisi, karena dengan proses pembelajaran yang seperti biasa yang dilakukan oleh guru membuat siswa bosan pada proses pembelajaran.

Tabel 1 Proses pembuatan media gambar tiga dimensi pop up

\begin{tabular}{|l|l|}
\hline Alat dan Bahan & $\begin{array}{l}\text { Prosedur } \\
\text { Pembuatan }\end{array}$ \\
\hline & $\begin{array}{l}\text { Gunting } \\
\text { merupakan alat } \\
\text { yang digunakan } \\
\text { untuk } \\
\text { memotong } \\
\text { gambar }\end{array}$ \\
\hline & $\begin{array}{l}\text { Lem digunakan } \\
\text { untuk } \\
\text { menempelkan } \\
\text { gambar pada } \\
\text { kertas konstruk }\end{array}$ \\
\hline \\
\hline
\end{tabular}

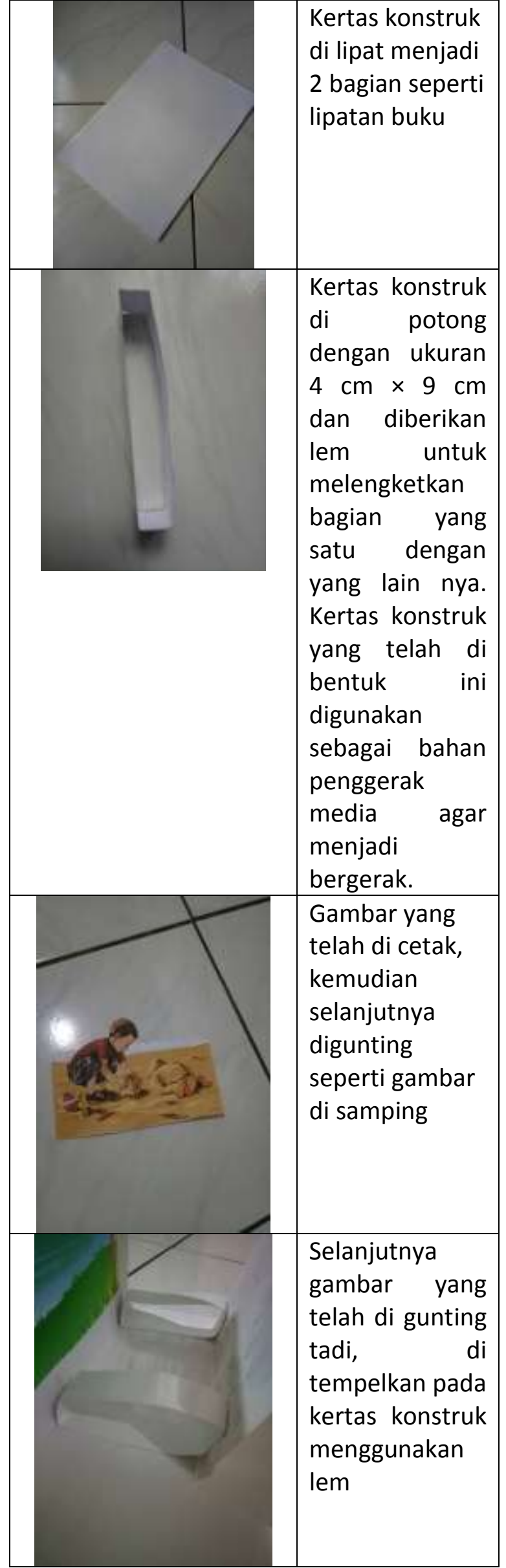




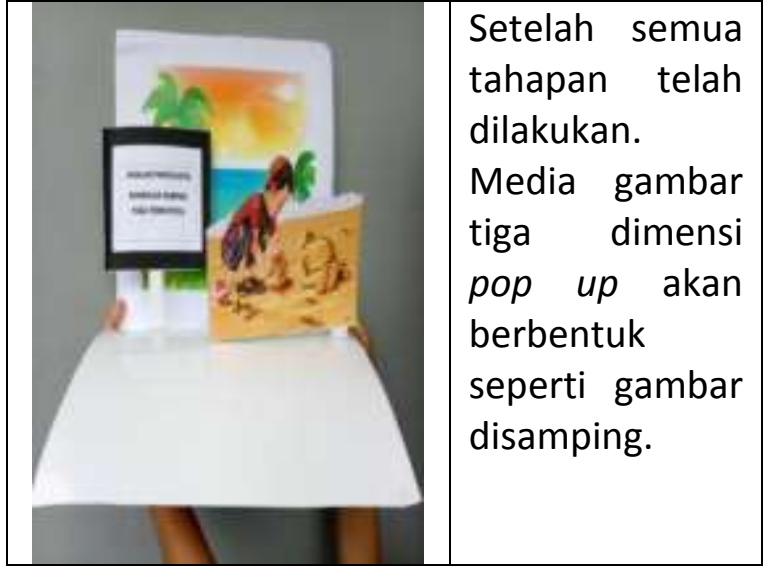

Setelah media gambar tiga dimensi di buat. Kemudian media digunakan untuk proses pembelajaran. Langkah-langkah dari kegiatan pembelajaran yang dilakukan oleh guru dan siswa yaitu pertama guru dan peserta didik bertanya jawab tentang proses penyusunan puisi yang pernah dialami atau dikenal siswa, kemudian guru memotivasi peserta didik bahwa menulis puisi itu mudah dan dapat dilakukan oleh siapapun. Selanjutnya, guru memperagakan media gambar tiga dimensi pop up dan kemudian siswa tertarik melihat media tersebut.

Setelah guru memberikan arahan kepada siswa, selanjutnya guru membagikan satu per satu media pop up. Siswa sangat antusias untuk membuat puisi. Karena baru pertama kali mereka melihat media gambar tiga dimensi pop up. Pertama dengan melihat gambar dan tulisan yang ada pada media. Selanjutnya siswa menentukan tema, diksi, gaya bahasa, persajakan, dan makna sesuai dengan media gambar tiga dimensi yang di dapat oleh siswa. Kemudian siswa mengembangkan imajinasi untuk membuat puisi. Dibawah ini terdapat data hasil menulis puisi siswa dengan menggunakan media gambar tiga dimensi pop up.

Aspek-aspek yang dinilai dalam penilaian puisi hasil kerja siswa, meliputi pilihan kata atau diksi, gaya bahasa, kesesuian judul,tema dan isi, persajakan dan kedalaman makna. Masing-masing aspek yang dinilai memiliki skor maksimum 5. Jika ditotal, skor maksimum praktik menulis puisi dalam penelitian ini adalah 25. Untuk penilaiannya total skor dibagi skor maksimum dikali 100 jadi nilai yang diperoleh siswa 100. Dari tabel di atas diperoleh data tentang kemampuan siswa dalam menulis puisi menggunakan media. Jumlah rata-rata hitung yang diperoleh siswa dari keseluruhan aspek yang dinilai adalah 76,96 atau jika dipersentasekan berjumlah 76,96 \%. Dari hasil pretes ini dapat dikatakan bahwa kemampuan siswa menggunakan media gambar tiga dimensi pop up kelas VIIIA SMPN 1 Ujan Mas dalam menulis puisi masih berkategori baik.

Kemudian kegiatan yang dilakukan peneliti selanjutnya adalah memberikan angket kepada siswa. Setelah media gambar tiga dimensi pop up digunakan pada proses pembelajaran menulis puisi. Peneliti memberikan angket kepada soswa. Siswa yang diberikan angket yaitu kelas VIIIA SMPN 1 Ujan Mas yang berjumlah 29 orang. Angket yang diberikan kepada siswa berisi pertanyaan-pertanyaan yang diikuti oleh lima pilih jawaban, yaitu: sangat setuju, setuju, ragu-ragu, tidak setuju, sangat tidak setuju.

Melalui penelitian ini, berdasarkan langkah-langkah analisis data yang telah dilakukan, maka gambaran yang dibahas dalam penelitian ini sudah jelas. Dalam proses penelitian, untuk mendapatkan hasil yang diiinginkan peneliti terlebih dahulu mengembangkan media. Pengembangan media dilakukan dalam beberapa tahap. Pada langkah awal, peneliti memilih materi dengan berpedoman pada Standar Kompetensi (SK), Kompetensi Dasar (KD), indikator dari silabus semester 2 kelas VIII SMP. Setelah memilih materi yang akan digunakan, langkah selanjutnya yakni merencanakan media yang akan dikembangkan dengan mendesain media 
pop up. Pop up yang telah selesai didesain kemudian di print dan dibentuk sesuai teknik pop up yang digunakan.

Uji coba dilaksanakan dua kali. Pertama, uji coba perorangan yang dilakukan tanpa media gambar tiga dimensi pop up dengan 29 reponden kelas VIII A SMPN 1 Ujan Mas dengan hasil kurang. Selanjutnya uji coba kedua menggunakan media gambar tiga dimensi pop up. Uji coba terbatas yang dilakukan dengan 29 responden dengan hasil baik. Berdasarkan hasil yang diperoleh, media pop up telah layak digunakan sebagai media pembelajaran Bahasa Indonesia kelas VIII SMP.

Presentase yang dihasilkan siswa ketika menulis puisi tanpa menggunakan media adalah $65,79 \%$ sedangkan presentase menggunakan media gambar tiga dimensi pop up adalah 76,96\%. Terdapat peningkatan ketika menulis puisi menggunakan media. Seperti yang diungkapakan oleh Sanaky (2009:3) bahwa media adalah alat bantu. Ketika proses pembelajaran menggunakan media gambar tiga dimensi pop up siswa menjadi lebih mudah untuk menentukan tema, serta pilihan kata yang akan mereka tulis dalam bentuk puisi.

Arsyad (2014:2) menyimpulkan bahwa media adalah bagian yang tidak terpisahkan dari proses belajar mengajar demi tercapainya tujuan pendidikan pada um umnya dan tujuan pembelajaran di sekolah pada khususnya. Pernyataan ini mengajarkan peneliti bahwa media memiliki peran penting dalam membantu guru untuk mengajar dan membantu siswa untuk mudah memahami pelajaran demi tercapainya tujjuan dari pendidikan itu sendiri, yang pada dasarnya adalah untuk mencerdaskan kehidupan bangsa.

\section{PENUTUP \\ Kesimpulan}

Berdasarkan penelitian yang dilakukan terhadap pengembangan media gambar tiga dimensi pop up dalam menulis puisi di kelas VIII SMPN 1 Ujan Mas, maka dapat disimpulkan bahwa media gambar tiga dimensi dapat membantu siswa dalam menulis puisi. Dengan menggunakan media siswa akan lebih mudah untuk menuliskan ide-ide yang ada dalam pikiran siswa.

\section{Saran}

Memperhatikan hasil penelitian dan pembahasan yang telah dilakukan, maka penulis mengajukan saran yang berkaitan dengan pemanfaatan penelitian ini, sebagai berikut: gunakan lah media pembelajaran agar proses pembelajaran menjadi lebih efektif, dan jangan hanya menjadi manusia yang konsumtif terhadap media dan berusaha lah untuk menjadi manusia yang produktif terhadap media.

\section{DAFTAR PUSTAKA}

Arsyad, A. 2014. Media Pembelajaran. Jakarta: PT RajaGrafindo Persada.

Dzuanda, B. 2009. Perancang buku Cerita Anak Pop Up. Surabaya: Institut Teknologi Sepuluh November.

Ganie, T. N. 2015. Buku Induk Bahasa Indonesia. Yogyakarta: Araska.

Kosasih, E. 2008. Apresiasi Sastra Indonesia. Jakarta: PT Perca.

Sanaky, A. 2009. Media Pembelajaran. Yogyakarta: Safira Insania Press.

Sugiyono. 2014. Metode Penelitian Kuantitatif Kualitatif dan R\&D. Bandung: Penerbit Alfabeta. 
Syaodih, N. 2010. Metode Penelitian Pendidikan. Bandung: PT Remaja Rodsa Karya.
Wahyuni, R. 2014. Kitab Lengkap Puisi, Prosa, dan Pantun Lama. Jakarta: Saufa. 